\title{
The right to take collective action in EU law based on the European Pillar of Social Rights and the recent case law of the CJEU
}

\begin{abstract}
This paper is built around the workers' fundamental right to take collective action and collective bargaining. Although, this right is firmly embedded in the majority of labour law systems in the social policy (meaning labour law, too) of the European Union, it is worth analysing it separately with an independent meaning. We can approach this right from the fundamental rights, the fundamental treaties or from certain directives, so we can find several questions that are difficult to answer properly. These problems are mostly catalysed by the necessary collision between the need for socially motivated legal protection and the fundamental economic freedoms. In my research, I analyse this right - along with some other connected ones - with the help of the recent case law of the Court of Justice of the European Union and the European Pillar of Social Rights because the latter highlights the holistic approach in the current reforms of EU social policy.
\end{abstract}

Keywords: Charter of Fundamental Rights of the European Union, collective labour law, European Pillar of Social Rights, fundamental labour rights, right to take collective action, social policy of the European Union

\begin{abstract}
ABSZTRAKT
Jelen tanulmány a kollektív fellépéshez és megállapodáshoz való alapvető munkavállalói jog köré épül. E jogosultság szilárdan beágyazott ugyan a munkajogi szabályozások többségében, de az Európi Unió szociálpolitikájának (munkajogi szabályainak) köszönhetően önállóan, sajátos jelentéstartalommal is vizsgálatra érdemes. Akár alapjogi, akár alapszerződési, akár irányelvi oldalról közelítünk e jog felé, annak tartalma és gyakorlati hatékonysága számos nehezen megítélhetó kérdésre mutat, ezeket pedig a szociális természetủ jogvédelem iránti igény és a gazdasági alapszabadságok szükségszerü kollíziója katalizálja. Kutatásom során e jog - kiegészítve néhány további, kapcsolódó kollektív munkavállalói jogosultsággal - vizsgálatát az Európai Unió Bíróságának újabb itélkezési gyakorlata, illetőleg a Szociális Jogok Európai Pillére jelentette átfogó szociálpolitikai reform segítségül hívásával elemzem.
\end{abstract}

Kulcsszavak: Európai Unió Alapjogi Kartája, uniós szociálpolitika, kollektív fellépéshez való jog, kollektív munkajog, munkavállalók alapvető jogai, Szociális Jogok Európai Pillére

Though traditionally the relation of collective legal instruments of workers is regarded as correlative to the individual side of the employment relationship, ${ }^{1}$ the legal nature, regulative method or the practical enforcement of the former is significantly different from the latter. It is also a generally accepted thesis that the unity of the

\footnotetext{
* Dr. Márton Leó Zaccaria, senior lecturer, University of Debrecen (Hungary) Faculty of Law Department of Environmental Law and Labour Law, zaccaria.marton@law.unideb.hu. This paper was supported by the János Bolyai Research Scholarship of the Hungarian Academy of Sciences.

${ }^{1}$ Kiss, György: Munkajog. Osiris, Budapest, 2005, 313.
} 
labour law regulation is due to - among other factors - the special duality of the collective and individual labour law norms. ${ }^{2}$ Namely, all legal instruments in connection to the employment relationship, and norms strengthening the legal status of workers, represent the same attributes, of course, with regard to their function. The regulation, method and the level of legal protection are definitely different with regards to the protective means in individual relations and in relation to the rights of the community of workers. However, nowadays both regulative sub-areas are changing, and regarding the collective legal institutions - which is the topic of this paper - it is clear that the technical and market conditions of the $21^{\text {st }}$ century do not leave unaffected ${ }^{3}$ the otherwise traditional ${ }^{4}$ field of labour law.

At the same time, in my opinion, the basic premise ${ }^{5}$ of collective rights is unchanged, since they cover such defined interests and rights above the level of the individual employment relationship, which can affect the content of the employment relationship, and consequently, the labour market itself with regards to their strength as fundamental rights and the typical direct state regulation. ${ }^{6}$ However, on interpreting this influence they necessarily can be described ${ }^{7}$ as the protection on the workers' side, to be more correct, the aim is to establish such a balance in different ways as the means which were used generally on an individual level, consequently, to balance the unequal economic positions of the parties would be possible. ${ }^{8}$ Furthermore, because of the traditional function of the regulation of labour law, collective instruments can play an important role in the workers' social-type interests. Its explanation is that with the strength of the joint action against the employer such circumstances, contractual clauses or advantages can come into the focus of the negotiations, which would be less possible on individual level. ${ }^{9}$ Moreover, workers cannot excercise some rights individually, since regarding legal dogmatics and the real interests of the society they are of different nature from those that are exclusively relevant to the given parties' employment contract. ${ }^{10}$

This paper does not aim to be exhaustive with regards to the identified topic, and mainly, due to the length limit, it selects from the Court of Justice of the European Union's (hereinafter: CJEU) cases of the previous period - since decisions on the

${ }^{2}$ Kiss, György: Alapjogok kolliziója a munkajogban. Justis, Pécs, 2010, 435, 483-484.

${ }^{3}$ Rácz, Ildikó: A kollektív jogok érvényesülésének lehetőségei a platform-munkavégzés esetében. Miskolci Jogi Szemle, 2018/2, 144-147.

${ }^{4}$ Deakin, Simon-Morris, Gillian S.: Labour Law. Hart, Oxford-Portland, 2009, 675-677. (doi: 10.1111/j.14682338.2010.00605.x).

${ }^{5}$ Kiss (2010): op. cit., 515.

${ }^{6}$ Barnard, Catherine: EU Employment Law. Oxford University Press, Oxford, 2012, 657-658.

${ }^{7}$ Supplemented by the collective agreement in an optimal case with regard to the interests of both sides.

${ }^{8}$ Prugberger, Tamás-Nádas, György: Európai és magyar összehasonlitó munka- és közszolgálati jog. Wolters Kluwer, Budapest, 2014, 497-498, 506-508.

${ }^{9}$ This means the greater influence of the community of workers against the employer's excessive power and stronger possibilities of the remedy of needs in comparison with the individual level. See: Kiss (2005): op. cit., 313-315.

${ }^{10}$ Such right is the right to strike, or any kind of industrial action beyond the peaceful dispute settlement. See: Prugberger, Tamás-Nádas, György: Európai és magyar összehasonlitó kollektív munkajog. Budapest, Wolters Kluwer, 2015, 145-146, 162-172. 
merits were made in reference to the Charter of Fundamental Rights of the European Union (hereinafter: CFREU) - regarding the right to take collective action. Of course, the analysis covers some fundamental right issues and the theoretical background to a certain extent, but in order to actualise the research in this circle I am examining the European Pillar of Social Rights (hereinafter: EPSR). ${ }^{11}$ I do not plan to analyse Article 28 of the CFREU in detail because my focus is on the EPSR regarding the regulative side and Article 28 will appear in my analysis based on the case law of the CJEU. However, only a small number of cases are available in the defined subject, and I think their analysis is important, since when we generally speak about the level of the legal protection of workers we should take into consideration the practical appearance of the collective labour law institutions regulated as fundamental rights, its anomalies, and conclusions. With the conclusions, I would like to synthetise all these factors, and to describe at which stage the development of these rights is right now and what can be the direction of the further evolution taking into consideration eminently the necessity of the protection of workers. Consequently, the focus of this paper is how the accompanying individual rights of workers can reflect the collective rights and freedoms guaranteed on the level of fundamental rights, namely, to what extent the collective rights support the legal protection of the individual rights in the framework of the changing labour market. Furthermore, this study does not aim to examine the detailed dogmatic or regular aspects of these rights either. I will first focus on the importance of these rights, their dynamism that can be experienced these days, and on the potential changes and effects - based on fundamental rights - in EU law. In addition, the CJEU's case law can ensure a reliable assumption in relation to the principles and rights mainly stated in the EPSR.

\section{Hypothesis - the strengthening of collective labour rights is necessary}

This topic is up-to-date by the acceptance of the EPSR and the developments in social policy and labour law since then, besides the current judicial practice of the CJEU. It is important that Article 8 of the EPSR states the right to take collective action independently, among twenty fundamental social rights and principles but other articles also closely relate to this group of norms. ${ }^{12}$ The following line of thought is mainly focused on the importance of fundamental collective labour rights in EU law. The analysis pays attention to both the traditional ways of this kind of regulation and the current developments showing up in EPSR.

Naturally, it would be difficult to deduce the hypothesis from only one article of the EPSR in relation to the development of collective labour rights, however, in spite of

\footnotetext{
11 https://ec.europa.eu/commission/sites/beta-political/files/social-summit-european-pillar-social-rights-booklet_ en.pdf (11. 27. 2019.).

12 EPSR Article 4 (active support to employment), Article 5 (secure and adaptable employment), Article 6 (wages), Article 7 (information about employment conditions and protection in case of dismissals) and Article 10 (healthy, safe and well-adapted work environment and data protection).
} 
all inconsistencies and difficulties of the EPSR ${ }^{13}$ some signs point into the direction that this time real labour law legislation will follow the social decisions and declarations. It is of high importance that the EPSR regulates various forms of the fundamental social rights, since the well-known labour and social law problems appear in three key areas ${ }^{14}$ like social inclusion or equal opportunities to access the labour market. In spite of this holistic approach - complemented with the indefinite legal character of the EPSR ${ }^{15}$ - we have already witnessed some new directives and further initiatives ${ }^{16}$ in this field, and we can conclude that among the Member States this kind of cooperation and EU legislation will increase in the coming years.

Undoubtedly, collective labour rights bear the nature of fundamental rights in EU law ${ }^{17}$ but their evaluation is rather difficult due to their regular restriction and limitation..$^{18}$ In the CFREU, the drafting of these rights' content is similar..$^{19}$ On the one hand, it has a positive effect on the social rights, since the decision maker does not try to separate this group of rights from its existing pillars; and on the other hand, the quasi repetition of these rights among the articles of the EPSR seems strange. Obviously, the content of the EPSR itself cannot place these rights on a higher level of legal protection; what is more, we can conclude that at present this level is low. It justifies that their regulation must be made in the circle of the most fundamental social rights in order to keep their importance, even though we can speak about the Treaty on the Functioning of the European Union (hereinafter: TFEU) in this regard. In other words, it is clear that the EPSR tries to strengthen the already existing rights in this area, too, and although the above-mentioned issues of labour market and labour law would require other approaches, my hypothesis is that the return to the traditional means of legal protection can be seen in this field. Lagging modernisation can legitimate the lower level legal protection, but on analysing the question it is worth examining that Article 8 of the EPSR and further regulations connected to that before we try to reflect on this challenge with regards to judicial practice.

${ }^{13}$ Hendrickx, Frank: Editorial: The European pillar of social rights: Interesting times ahead. European Labour Law Journal, 2017/3, 191-192. (doi: 10.1177/2031952517725595).

${ }^{14}$ EPSR chapter I (Equal opportunities and access to the labour market), chapter II (Fair working conditions) and chapter III (Social protection and inclusion).

${ }^{15}$ Hendrickx, Frank: The European Social Pillar: A first evaluation. European Labour Law Journal, 2018/1, 5-6. (doi: 10.1177/2031952518759987).

${ }^{16}$ Directive (EU) 2019/1152 of the European Parliament and of the Council of 20 June 2019 on transparent and predictable working conditions in the European Union (OJ L 186, 11.7.2019, p. 105-121); Directive (EU) 2018/957 of the European Parliament and of the Council of 28 June 2018 amending Directive 96/71/ EC concerning the posting of workers in the framework of the provision of services (OJ L 173, 9.7.2018, p. 16-24); Regulation (EU) 2019/1149 of the European Parliament and of the Council of 20 June 2019 establishing a European Labour Authority, amending Regulations (EC) No 883/2004, (EU) No 492/2011 and (EU) 2016/589 and repealing Decision (EU) 2016/344 (OJ L 186, 11.7.2019, p. 21-56).

17 Kiss (2010): op. cit., 446.

${ }^{18}$ Kiss (2010): op. cit., 453.

${ }^{19}$ Article 27 of the CFREU is about the workers' right to information and consultation within the undertaking, while Article 7 of the EPSR is on the right to information about the conditions of employment. Similarly, we can see a parallel in the relevance of Article 28 and 8 (the right to take collective action and bargaining, amended with the workers' participation). 


\section{The European Pillar of Social Rights as an old-new source of collective labour rights}

Article 8 of the EPSR contains the collective labour rights under the title "social dialogue and involvement of workers." Evidently, Article 8 matches with the second chapter of the EPSR, which is about fair working conditions, and strengthens the fundamental right ${ }^{20}$ to information and consultation. ${ }^{21}$ One of the EPSR's declared aims is to establish and promote the fair and just working conditions, ${ }^{22}$ and its relevance to EU law links them to Article 30 and 31 of the CFREU. Namely, we do not think of necessarily new regulations or principles in this regard either. ${ }^{23}$

At the same time, in my opinion, with this approach to the collective rights we can discover some kind of novelty. According to my standpoint, their integration to the twenty fundamental social principles is regarded as the most important one,$^{24}$ and emphasising these rights in independent articles - according to my hypothesis - justifies that these rights are necessary in the changing framework of the labour market; what is more, their strengthening may belong to the priorities in the near future. It should be added that fair working conditions cover regulations on both an individual and collective level, consequently - based on Article 155 and 156 of the TFEU - their regulation will be more stressed on an EU level, and this will be the great responsibility of the social partners at the same time. ${ }^{25}$ The EPSR reacts to this special situation when imposes closer co-operation of the Member States in this field, and what is more, the EPSR pays special attention to these principles referring to the cross-border collective rights of the social partners and the workers. ${ }^{26}$ This way it can be prevented that that owing to the weaker influence of trade unions the employer would resolve unilaterally such issues which otherwise would belong to social dialogue.$^{27}$ Before going into details with regards to Article 8 of the EPSR, it is important to add that some of my ideas are only based on the problematic legal character of the EPSR meaning that its real legal power is still a question. Although, some new laws or some amendments seem to be possible even in the field of collective labour

20 See the heavily related Directive 2002/14/EC of the European Parliament and of the Council of 11 March 2002 establishing a general framework for informing and consulting employees in the European Community - Joint declaration of the European Parliament, the Council and the Commission on employee representation (OJ L 80, 23.3.2002, p. 29-34).

${ }^{21}$ Blanke, Thomas: Workers' right to information and consultation within the undertaking (Article 27). In: Bercusson, Brian (ed.): European Labour Law and the EU Charter of Fundamental Rights. Nomos, Baden-Baden, 2006, 280-289.

22 EPSR Chapter II.

${ }^{23}$ Hendrickx (2017): op. cit., 191.

24 The twenty articles of the EPSR cover not only traditional principles of labour law and employment, but also contains - with holistic approach - a wide range of social rights.

${ }_{25}$ Although, social dialogue and co-operation of collective partners both have had a significant role since the beginnings of social policy. See: Schubert, Claudia: Collective Autonomy as Part of the European Economic System. European Labour Law Journal, 2013/3, 147-153. (doi: 10.1177/201395251300400302).

26 TFEU Article 155.

27 Pecinovsky, Pieter: EU Economic Governance and the Right to Collective Bargaining: Part 2. From imposed restrictions of the right by EU Member States towards a social economic governance. European Labour Law Journal, 2019/1, 44. (doi: 10.1177/2031952518817564). 
rights, some questions still need to be answered in the near future in this sense. Therefore, my following analysis is based on the principles and the background of the EPSR along with some possible new approaches for the future.

\subsection{The right to take collective action in the EPSR}

Point a) of Article 8 though, in accordance with the national practices, but universally as a whole, orders in line with the workers' right to take collective action, to support the social dialogue, which must be as broad as possible including economic, employment and social issues. From the wording of the article, we can conclude that it is a fundamental requirement from the side of the EPSR that workers can exercise these rights and can influence in merit the regulations of these issues or the declaration of the directions. In my opinion it is possible only if real legal means would fall into the hands of the workers' community, namely, it would be useful to meditate on the method of practice and restriction of the right to collective action, ${ }^{28}$ which was emphasised with good reason. In order to fulfill this purpose point a) - in a summary manner - offers collective agreements as a means to realise the social dialogue. On this basis, the Member States should endeavour for workers' real participation in economic proceedings, moreover, employers and decision makers should ensure this possibility even in special legal forms, that is, collective agreement.

At the same time, besides domestic level regulation and enforcement the EPSR specifies the requirement that these agreements must be enforced and applied on an EU level, which emphasises again the importance of the cross-border social dialogue. However, we can also conclude that the declaration itself is not enough of a guarantee for the workers. That is why it must be strengthened by such concrete acts as the right to conclude collective agreements or the right to take collective action. The latter is important even if the EPSR is now merely rooted in fundamental rights, but it is also a declaration. ${ }^{29}$ So, "in a given case" the EPSR counts on actors on both levels, which justifies the assumption that collective rights and the representation of interests should also be reconsidered and strengthened on the EU level. The main reason for this is as follows: such contradictions like the expectation, which is the interest of the market in general, namely, the interest of the social partners, in spite of the fact that the right to strike is regarded as a fundamental right in EU law as well. ${ }^{30}$

${ }^{28}$ The limitations are realised in case of the conflicts with the fundamental freedoms. See: Kiss (2010): op. cit., $446-453$.

29 Lörcher, Klaus-Schömann, Isabelle: The European pillar of social rights: critical legal analysis and proposals. European Trade Union Institute, Brussels, 2018, 5-8.

${ }^{30}$ Göndör, Éva-Ferencz, Jácint-Trenyisán, Máté: A munkaküzdelemhez való jog. In: Ferencz, Jácint (ed.): A munkaügyi kapcsolatok joga Magyarországon. Gondolat, Budapest, 2019, 112. 


\subsection{Workers' right to information and consultation}

Point $b$ ) revives a typically traditional collective labour right, the workers' right to being informed, receiving information, the right to information in good time ${ }^{31}$ which is in close connection to Article 7 as mentioned before. The comprehensive reform of the directive on employer's obligation to inform the worker can be one of the guiding principles ${ }^{32}$ regarding the employment contracts carried out within the framework of the EPSR, though the latter provides on it on individual level, but the directive itself also covers collective labour law aspects. ${ }^{33}$ The right to information typically concerns every worker, so, it is very important that EU law ensures it on the level of fundamental rights, ${ }^{34}$ and the EPSR confirms it on the level of such basic principles. Workers are exposed to the changes, risks on the transformation which emerge on the employer's side, and of course, the employees have no influence on them, consequently, in point $b$ ) such cases can be seen in the circle of the very important obligation of giving information. It can be stated that the EPSR alludes to the right to information and receiving information referring to the whole community of the workers among the most fundamental social rights.

It is necessary to add that Article 14 of the mentioned new directive on transparent and predictable working conditions, ${ }^{35}$ which is in close relation to these rights, pays special attention to such agreements of the social partners, which can differ from substantial parts of the legal protection laid down in the directive. ${ }^{36} \mathrm{At}$ the same time, it is important that the protection level of workers cannot be lower than the level stated in the directive, but it should be emphasised that in such important questions the legislator strongly relies on the social partners. I think these joint rights should also be strengthened maybe by some amendments in the legislation. Alternatively, I suppose the CJEU should reveal the core of these rights in the near future - taking into consideration the EPSR itself - because the effective enforcement or at least the real possibility for workers to use these rights lacks some legal support on the workers' side.

${ }^{31}$ Berke, Gyula: A munkáltató tájékoztatási kötelezettsége a foglalkoztatási feltételekröl. In: Kiss, György (ed.): Az Európai Unió munkajoga. Osiris, Budapest, 2003, 317-318.

${ }^{32}$ Communication from the Commission to the European Parliament, the Council and the European Economic and Social Committee - Monitoring the implementation of the European Pillar of Social Rights. COM(2018) 130 final, 6.

${ }^{33}$ Article 14 of Directive (EU) 2019/1152 allows the social partners to conclude collective agreements, which differ from the Directive's regulations on fundamental working conditions, although the guaranteed level of protection must be kept.

${ }^{34}$ Proposal for a Directive of the European Parliament and of the Council on transparent and predictable working conditions in the European Union. $\operatorname{COM}(2017) 797$ final, 2, 10.

${ }^{35}$ Council Directive 91/533/EEC of 14 October 1991 on an employer's obligation to inform employees of the conditions applicable to the contract or employment relationship lapsed and Directive (EU) 2019/1152 entered into force on 20 June 2019.

${ }^{36}$ Article 8-13 of Directive (EU) 2019/1152 (maximum of probationary period, parallel employment, mandatory training, etc.). 


\subsection{On the importance of social dialogue}

Point c) - as an amendment to the above-mentioned issues - is about the obligation of increasing the capacity of social dialogue. Although, at first sight, it is not quite clear what the EPSR means by this, it is supposed that the following issues belong to it: involving as many social partners as possible, concluding as many agreements as possible and achieving as effective law enforcement as possible. Importantly, at present it is a conceptual decision that the EPSR intends to motivate, what is more, to oblige the Member States to respect, even to support the interests of workers as widely as possible. In my opinion, the EPSR - with all its disadvantages and uncertainties - is indicative, since it states definite and mainly transparent requirements regarding collective rights and social dialogue (not only on a national level). Consequently, it supports the increase of the effectiveness of the legal protection and the closer co-operation between the labour market players and social policy in motion.

In summary, with regards to all the above concerning the EPSR, in my opinion, the guiding principle of collective labour rights - a simultaneous discretion of the different forces on the opposite sides ${ }^{37}$ - seems to be a basic, even difficult requirement in the changing market climate. It is justified by the above-mentioned relevances of fundamental social rights and the relevant directives. The most important aspect from among all this is the fundamental right to take collective action and the legal support of social dialogue, which covers the workers' interests the best. Referring to this, this right is in the focus of my further analysis.

\section{The recent case law of the CJEU in the field of the right to take collective action and collective bargaining}

\subsection{Methodological overview}

Although the first part of this paper is built around the regulative approach, regarding the right to take collective action in EU law I also promised in the beginning of my analysis to take into consideration the relevant recent case law of the CJEU. It is clear that the exact content and scope of Article 28 of the CFREU cannot be understood on its own, not only because of the possible new approach based on the EPSR. I am not trying to see into the future in the following but I will give some ideas for the closing conclusions regarding the specialities and current development of this right keeping an eye on the EPSR as well. Firstly, I am focusing on the aforementioned case law with special regard to the fundamental right-nature of the collective labour rights and their possible emergence for the sake of workers' effective legal protection.

Accordingly, in the following, I am interpreting the essence of Article 28 of the CFREU and obliquely, Article 8 of the EPSR through some current decisions of the

${ }^{37}$ Weiss, Manfred: The future of labour law in Europe: Rise or fall of the European social model? European Labour Law Journal, 2017/4, 348. (doi: 10.1177/2031952517743860). 
CJEU emphasising the current trends in the interpretation, or restrictions of these important labour rights. Most of the analysed judgments were published after the CFREU entered into force, which was an important aspect of the selection during my research. On the one hand, the relevant judgments before 2009 are already presented in detail, ${ }^{38}$ and on the other hand, the past period of nearly ten years and the EPSR can be the correct standard of the analysis and context of the fundamental collective rights for the coming years. My aim is to justify my hypothesis through some relevant practical examples. I think that collective labour rights are changing together with the labour market, but the "back to the roots" aspect - which is also emphasised by the EPSR - namely, the aspect of the focus on strong and effective legal protection is not unprecedented and may have a significant effect on the processes, trends of the developments of the fundamental labour and social rights in the near future. I build the analysis around the fundamental right stated in Article 28 of the CFREU.

\subsection{Collision between the workers' social protection and the freedom to conduct a business}

We can observe a typical situation of collisional legal interpretation in judgment C-426/11, ${ }^{39}$ where - among others -, even through other regulations of the CFREU, the workers' right to take collective action and negotiations got into the focus of the interpretation of the CJEU. It is clear that in reference to Article 28 of CFREU workers are entitled to these rights with proper binding force, but the content and the practical limits of these rights can be uncertain, mainly, when collective rights are confronted with economic freedoms. The former belong to the most fundamental social rights, ${ }^{40}$ but when applying them the CJEU has to pay close attention that they comply with the other (economic) fundamental rights and freedoms, and it is also important that regarding their regulation and legal nature they extend beyond the fundamental freedoms. ${ }^{41}$

Furthermore, based on the case we can raise the question as whether the protection of the workers' social and economic interests can be overriden, or whether this protection can override the effectiveness of other, clearly economic rights. In any

\footnotetext{
${ }^{38}$ Hős, Nikolett: A svéd munkaügyi bíróság Laval ügyben hozott döntése a szakszervezetek kártérítési felelősségével kapcsolatban. Pécsi Munkajogi Közlemények, 2010/1, 95-104; Hős, Nikolett: Közösségi jog - tagállami munkajog - az Európai Bíróság Viking- és Laval esetekben hozott döntéseinek jelentősége. Európai Jog, 2008/1, 21-35; Kiss, Lilla Nóra: A Landmark Decision: the Laval-case and its Further Judicial Questions. European Integration Studies, 2015/1, 71-80; Freedland, Mark-Prassl, Jeremias (eds.): Viking, Laval and Beyond. Hart, Oxford, 2015. (doi: 10.1017/S0008197315000379).

39 Judgment of 18 July 2013, C-426/11 Mark Alemo-Herron and Others v Parkwood Leisure Ltd (ECLI:EU:C:2013:521).

${ }^{40}$ Advocate General Bot's opinion (paras. 62, 112-113) in Judgment of 27 April 2017, C-680/15 and C-681/15 Asklepios Kliniken Langen-Seligenstadt $\mathrm{GmbH}$ v Ivan Felja and Asklepios Dienstleistungsgesellschaft $\mathrm{mbH}$ v Vittoria Graf (ECLI:EU:C:2017:317).

${ }^{41}$ Bavaro, Vincenzo-Pietrogiovanni, Vincenzo: A hypothesis on the economic nature of labour law: The collective labour freedoms. European Labour Law Journal, 2018/3, 264-266. (doi: 10.1177/2031952518799761).
} 
case, to what extent are the workers' collective freedoms, as basis of the question, of social or economic nature..$^{42}$ In the case of transfer of an undertaking one of the most important guarantees is that the collective agreements covering the given workers are transferred to the transferee, ${ }^{43}$ but of course, workers have the possibility to rediscuss the agreements with more advantageous possibilities. However, it is important that this right, which can be traced back to the right to take collective action, cannot be contradictory to the freedom of contract regulated in Article 16 of the CFREU. It means that the contractual latitude of the transferee cannot be restricted as the workers abusing the right to collective negotiations would leave the new employer (the transferee) out from the discussions, namely, the transferee cannot influence substantially the previously negotiated working conditions. Undoubtedly, according to the relevant directive workers have the right to more advantageous working conditions, ${ }^{44}$ but to negotiate conditions is only possible with mutual consent, namely, with involving every affected parties. According to Prassl, the judgment can be interpreted as the CJEU attributes a special meaning to the contractual freedom referred to labour law as Article 16 of the CFREU. ${ }^{45}$

Altogether, the important limitation of the right to take collective action and bargaining is that the enforcement of more advantageous working conditions of the workers - and in general, the freedom of collective action - cannot override the border of the contractual autonomy. Namely, neither the CFREU nor Directive 2001/23/ EC ensures a proper legal basis for the forced but bargained more advantageous working conditions, which is considered regarding the level of the legal protection of the workers. ${ }^{46}$ It is clear that the fundamental right to conduct a business cannot be restricted even by the workers' right to collective action protecting their social rights, especially if workers practically used this right improperly. It is sustained by the fact that after the transfer of the undertaking the conditions of the collective agreement were discussed but the transferee employer could not take part in the negotiations. This may cause the breach of fundamental economic rights on the side of the transferee. ${ }^{47}$

The CJEU confirmed all this in a later decision, since in judgment C-680/15 and C-681/1548 Article 16 of the CFREU and the above-mentioned Article 3 of Directive

42 Bavaro-Pietrogiovanni: op. cit., 274-283.

${ }^{43}$ Paragraph (3) of Article 3 of Council Directive 2001/23/EC of 12 March 2001 on the approximation of the laws of the Member States relating to the safeguarding of employees' rights in the event of transfers of undertakings, businesses or parts of undertakings or businesses (OJ L 82, 22.3.2001, p. 16-20).

${ }^{44}$ Barnard: op. cit., 608-610.

${ }^{45}$ Prassl, Jeremias: Freedom of Contract as a General Principle of EU Law? Transfers of Undertakings and the Protection of Employer Rights in EU Labour Law. Industrial Law Journal, 2013/4, 440-442. (doi: 10.1093/ indlaw/dwt017).

${ }^{46}$ Prassl: op. cit., 445-446.

${ }^{47}$ See the importance and analysis of the judgment in Berke, Gyula: Az Európai Unió Alapjogi Chartájának alkalmazása munkajogi (szociálpolitikai) ügyekben. HR \& Munkajog, 2014/11, 10-14; Zahn, Rebecca: The Court of Justice of the European Union and Transfers of Undertakings: Implications for Collective Labour Rights. European Labour Law Journal, 2015/1, 73-79. (doi: 10.1177/201395251500600105).

48 Judgment of 27 April 2017, C-680/15 and C-681/15 Asklepios Kliniken Langen-Seligenstadt GmbH v Ivan Felja and Asklepios Dienstleistungsgesellschaft mbH v Vittoria Graf (ECLI:EU:C:2017:317). 
2001/23/EC collided. The CJEU had to make decision in reference to the dynamic clauses of the collective agreement, which were negotiated before the transfer. It is a question whether the legal protection ensured by Article 3 of the Directive can entitle the workers during the collective bargaining to negotiate with the transferor such contractual clauses that have to be applied by the transferee even if in the meantime the agreement will be modified or complemented. Practically, we are speaking about the negotiation of such dynamic clauses, which cannot be influenced by the transferee, but which are effective at the time of transfer, what is more, their original source is the contract in force that directly refers to the negotiation of the collective agreement. ${ }^{49}$ The CJEU emphasises that this right unconditionally covers the cases in which the parties define statical contractual clauses either with individual employment contract or collective agreement, ${ }^{50}$ namely, they define such working conditions, which are given, known and unchanged at the time of the transfer.

From the Werhof judgment ${ }^{51}$ we can come to the conclusion that the rules of the Directive - though in my opinion not exclusively - refer to only those contractual regulations which are effective at the time of the transfer. Consequently, the Directive covers only the statical clauses, and it does not conclude from the fundamental right of the freedom to collective negotiation itself ${ }^{52}$ that the transferor can be pressed in this sense. However, with a broad interpretation, one can refer to trade unions as service providers - meaning special services for workers, social partners -, which makes it possible to directly refer to Article 56 of the TFEU if the employer does not accept the trade union as a negotiating social partner. ${ }^{53}$ This approach can make the right to take collective action more powerful in practice, although this possibility is argued but shows a new mode of workers' legal protection in this sense.

At the same time, in paragraphs 19-20 of the judgment the CJEU differentiates between the above-mentioned issues, and partly elaborates that it cannot be traced back to the directive - and in my opinion implicitly to Article 28 of the CFREU - as the legislator integrates only some special collective negotiations to the circle of legal protection. Consequently, it does not conclude the prohibition of dynamic regulations. It means that, in case the given negotiations and the rule of contract itself is known at the time of transfer, and it is a result of free negotiation, ${ }^{54}$ its transfer cannot be disclosed. At the same time, in the framework of Article 28 we must pay attention to the fact that besides the workers' legal protection in general the harmonisation between the interests of the social partners is at least as important an aim of the

\footnotetext{
${ }^{49}$ Advocate General Bot's opinion in C-680/15 and C-681/15 Asklepios Kliniken, paras. 69-70.

${ }^{50} \mathrm{C}-680 / 15$ and C-681/15 Asklepios Kliniken, paras. 16-17.

51 Judgment of 9 March 2006, C-499/04 Hans Werhof v Freeway Traffic Systems GmbH \& Co. KG. (ECLI:EU:C:2006:168).

${ }^{52}$ According to Van Cleynenbreugel based on the essence of this fundamental right trade unions can act as quasi legislators, which strongly supports the workers' legal protection. Although, such trade union activity can barely be interpreted as service under Article 56 of the TFEU. See: van Cleynenbreugel, Pieter: The freedom to receive trade union services: an additional stepping stone for enhancing worker protection within the EU internal market? European Labour Law Journal, 2018/2, 108. (doi: 10.1177/2031952518780042).

${ }^{53}$ Hungler, Sára: A szakszervezetek tevékenysége a szolgáltatásnyújtás szabadságának tükrében. Munkajog, 2019/3, 39.

${ }^{54}$ C-499/04 Hans Werhof, para. 21.
} 
relevant regulation. In this regard, even if we speak about a traditional workers' right, the co-operative side of this legal instrument also should be emphasised. Namely, this kind of collective legal practice can only be justified if the transferee - in the framework of contractual freedom - has the possibility to take part effectively in the bargaining and its preparation. This is also the duty of the legislator, but I would like to emphasise again that the new interpretation of the old legal means can be successful in handling the new, similar situations.

Based on the judgment one can state that the right to take collective action and bargaining guaranteed in the CFREU and the collective agreements arising in the case of transfer according to Directive 2001/23/EC conditions that are more advantageous for the workers must be safeguarded in case they negotiated these clauses before transfer. Under these circumstances, these newly negotiated conditions must be guaranteed even after the transfer. Namely, the CJEU emphasises that the right to collective negotiations should be taken into consideration not exclusively at a given time, at the negotiation and during the social dialogue, but due to its fundamental right nature the most advantageous possibilities for workers also must be ensured for the future, independently from the transfer. In paragraph 16 of the judgment the CJEU emphasises the defining difference between the "statical"55 and "dynamic" clauses of the collective agreement referring to the legal protection. ${ }^{56}$ Consequently, the contractual conditions respecting the parties' economic freedom - based on Article 16 of the CFREU - and the future changes of the negotiated relation along with the corrections as consequences can be justified.

Namely, according to the CJEU the "dynamic" clauses agreed before the transfer enjoy fundamental right-level protection of which explanation, in my opinion, can be found in the principle of contractual freedom and in the economic and social importance of the contractual negotiations. Furthermore, it is important that with regards to the substantial specialities of the collective agreement the CJEU emphasises the principle of the "freedom of the parties to arrange their own affairs." ${ }^{57}$ On this basis, the important novelty of the judgment is that owing to the requirement of keeping the harmony between the social partners the CJEU makes decision on the one hand, by explicitly stated legal protection of the right to collective negotiation, and on the other hand, by the definite interpretation of the above-mentioned restriction. In the focus of the collective dialogue, there is not necessarily the traditional guarantees of the principles of the legal protection of workers, but the contractual freedom of the parties. ${ }^{58}$ In other words, not (only) the powerful social-like legal protection is significant on the workers' side but the safeguarding of the collective bargainings based on mutual consent as well. However, the latter mirrors both parties' interests; therefore,

${ }^{55}$ According to C-499/04 Hans Werhof (para. 29), collective agreements are limited in time due to their legal nature (duration), and the subsequent unilateral modification is illegal even in the protection of the workers' interests (exclusion of the protection of the "mere expectations" and "hypothetical advantages").

${ }^{56}$ Advocate General Bot's opinion in C-680/15 and C-681/15 Asklepios Kliniken, paras. 29, 32, 45, 46, 52, 54, $57,62,81,95,104,105,106,107,109,110$.

57 C-680/15 and C-681/15 Asklepios Kliniken, para. 19.

58 See in details: Rab, Henriett-Zaccaria, Márton Leó: A kollektív munkajog eszközeinek megítélése a HR szempontjai alapján. Jura, 2018/1, 130-131. 
it seems to be a more practical and logic explanation than the traditional, socially focused legal protection for workers.

\subsection{The substantive components of the right to take collective action in current judgments of the CJEU}

EU law - though within limits and with the requirement of the necessary harmonisation - really takes into consideration this fundamental workers' right, as is mentioned in paragraph 22 of judgment C-149/10 59 in reference to the content of Article 155 of the TFEU. The social partners have a fundamental right to create the conditions with consent, and they also have this right with regards to the principle of contractual freedom; ${ }^{60}$ however, even based on this entitlement of the CFREU, they cannot extend beyond the content of Article 155 of the TFEU ${ }^{61}$ Naturally, it is a question as to whether on the level of fundamental rights the enforcement of collective negotiations or the right to place pressure on the employer can have common meaning in the social policy of the EU. ${ }^{62}$ Nevertheless, in my opinion, in the CFREU - or later in the EPSR - the fundamental character of this right would justify to state the framework of the interpretation more correctly besides emphasising the fundamental interests and rights. ${ }^{63}$ Mainly, but not exclusively the workers' interests belong to this circle.

However, the national case was about age discrimination and its possible outcome and justification, but I should mention judgment C-312/17 ${ }^{64}$ in this analysis on collective labour rights. Without interpreting the details of the state of facts, it should be mentioned that on the basis of Council Directive 2000/78/EC of 27 November 2000 establishing a general framework for equal treatment in employment and occupation the social partners are authorised to negotiate certain conditions of equal employment in collective agreement. In the concrete case, the social partners' negotiation in reference to persons with disabilities had a special construction about pension insurance benefits, ${ }^{65}$ but the regulative logic of the negotiation raised the suspicion of discrimination.

The basic legal dilemma emerged concretely with the components of Article 28 of the CFREU, based on the right to collective bargaining, since it was questionable in the case whether as a consequence of the social partners' negotiation the worker

\footnotetext{
59 Judgment of 16 September 2010, C-149/10 Zoi Chatzi v Ypourgos Oikonomikon (ECLI:EU:C:2010:534).

${ }^{60}$ CFREU Article 28.

61 See the CJEU's relevant narrowing interpretation: Kiss (2010): op. cit., 446-453.

62 According to Kiss in spite of the universal and original nature of the collective rights their assessment with the Union legal freedoms can be resolved with difficulties because of the latter's derivative character, consequently to establish united interpretation is difficult. See: Kiss (2010): op. cit., 453.

${ }^{63}$ Rab-Zaccaria: op. cit., 129.

64 Judgment of 19 September 2018, C-312/17 Surjit Singh Bedi v Bundesrepublik Deutschland and Bundesrepublik Deutschland in Prozessstandschaft für das Vereinigte Königreich von Großbritannien und Nordirland (ECLI:EU:C:2018:734).

${ }^{65}$ C-312/17 Surjit Singh Bedi, paras. 13-18.
} 
taking the given treatment ${ }^{66}$ can suffer from a legally disadvantageous situation. ${ }^{67}$ Regarding that Article 28 ensures a special kind of "protection"68 to every social partner, it is uncertain whether the practical application of this right can be restricted anyway, or to be more correct, which conceptual criteria are required for the bargaining of the social partners. Is it possible that the collective negotiation is disadvantageous as it was mentioned above to a certain group of persons, or can the collective negotiation contain clauses that are disconcerting from the aspect of receiving social security right in a given case ${ }^{69}$ on the pure basis that to establish this negotiation is the fundamental right of the social partners?

This is not a hypothetical question since Article 155 of CJEU, Article 8 of the EPSR, and Article 28 of the CFREU only authorise the social partners. However, it is the responsibility of the Member States to work out the detailed norms, but the collective dialogues on the European level, which pay attention to the common interests of economy and labour market, also involve the norms of labour and social regulation of EU law. What is more, through the EPSR, a special, comprehensive idea - focusing on social protection - is directly involved. I think that these connections emphasise that not even on the level of the detailed rules, but on the level of fundamental rights and freedoms, inserting the right to collective action into special context, it is necessary to clear the dilemmas in order to achieve successful legal enforcement in the future.

With reference to the Hennings and Mai judgment, ${ }^{70}$ the CJEU refers to the basic requirement of balancing the interests of social partners, which is really an important cornerstone of every employment law relation, ${ }^{71}$ but cannot be regarded as a legal norm to be enforced. Consequently, apart from this principle the essence of Article 28 of the CFREU is unclear, though from its original inspiration sources the conceptual essence of it can be found..$^{72}$ It seems natural that the laws of the Member States govern the exact content of these rights. At the same time, the relevant rules are decisive also on an EU level, regarding the fact that in a domestic legal dispute, what is the basis of the mentioned case; it is questionable whether the concrete content questions elaborated in an EU directive fall within the scope of Article 28. The previously mentioned balance between the social partners' interests is an extremely important element of this right, since the right to take collective action and bargaining involves the possible conflicts between the interests, and the solutions to them. In this regard, to clear the substance of the issues would be required, because the above-mentioned substantive explanation is the precondition of the justification of the conceptual basis interpreted in the case law of the CJEU. According to the draft-

${ }^{66}$ C-312/17 Surjit Singh Bedi, paras. 50-53.

${ }^{67}$ Advocate General Sharpston's opinion in C-312/17 Surjit Singh Bedi, para. 33.

${ }^{68}$ This qualification is in Germany's official position. See C-312/17 Surjit Singh Bedi, para. 67.

${ }^{69}$ For example, how or when can one be qualified an old-age pensioner or seriously disabled.

70 Judgment of 8 September 2011, C-297/10 and C-298/10 Sabine Hennigs v Eisenbahn-Bundesamt and Land Berlin v Alexander Mai (ECLI:EU:C:2011:560).

${ }^{71}$ Kiss (2010): op. cit., 453.

72 Veneziani, Bruno: Right of collective bargaining an action (Article 28). In: Bercusson, Brian (ed.): European Labour Law and the EU Charter of Fundamental Rights. Nomos, Baden-Baden, 2006, 297-335. 
ing of the judgment, the freedom of shaping the common interest is the responsibility of the collective partners. ${ }^{73}$ In this sense, their freedom in bargaining and making common decisions cannot be influenced. Paragraphs $60-70$ of the judgment state the most important restriction specifying that in case the given collective dialogue affects EU law, this right can be practiced only in accordance with that, the principle that the social partners have to respect the given directive. ${ }^{74}$

Altogether, the judgment reflects that the correct interpretation of Article 28 of the CFREU is based on three key elements: firstly, we should mention the bargaining and decision-making freedom of the social partners. Secondly, the importance of the endeavour for the harmonisation between the interests of the social partners, and thirdly, the obligation as a limit of the interpretation in accordance with EU law. Consequently, the fundamental rights realised in Article 28 are really of high importance regarding the special character of the collective labour rights, and typically, we have to interpret these fundamental rights in the traditional concept of labour law, accompanied with the EU law obligations, which are inevitable in the given legal circumstances.

\section{Conclusion}

In order to catalyse the above-described process of the development of Article 28 of the CFREU the fundamental rights themselves are not enough, even though it unambiguously expresses the most fundamental social rights. Although, these rights have been analysed in a small number of cases so far, and it seems that their enforcement and filling with content is a difficult process, EU law and national laws also have real traditions in this field. However, according to my standpoint - and this thought justifies the topicality of the research to a significant degree - Article 8 of the EPSR and altogether the interpretations heading towards the importance of the collective labour law institutions justify the following. According to the legislator, one cannot imagine a properly effective, flexible, but stable labour market from the point of social side and from the aspect of workers without emphasising and effectively promoting collective labour rights. At present the EPSR is mostly a theoretical background, but as consequence of the reforms in labour law to be achieved in a short time - regarding the directive on posting of workers ${ }^{75}$ and transparent and predictable working conditions and the regulation on the European Labour Authority ${ }^{76}$ - we can realise that this time the higher level of social protection as a clear decision is not only a declaration or a sounding expression of an important intention.

According to my standpoint, in this process collective labour law should have a key role, though, with regards to the previously analysed facts it would be an exaggerated

\footnotetext{
${ }^{73}$ C-297/10 and C-298/10 Sabine Hennigs and Alexander Mai, paras. 68-69.

74 Judgment of 12 December 2013, C-267/12 Frédéric Hay v Crédit agricole mutuel de Charente-Maritime et des Deux-Sèvres (ECLI:EU:C:2013:823), para. 67.

75 Directive 96/71/EC amended by Directive 2018/957.

${ }^{76}$ Regulation (EU) 2019/1149.
} 
statement that every sign points in this direction. However, within the changing framework of the labour market the institutions of collective labour law may be the reference point (or at least one of the reference points), which would ensure permanence, stability, even if their modernisation is inevitable, referring e.g. to the rights of workers working in special legal relationships like self-employers. ${ }^{77}$ Finally, I add that in reference either to the collective action, the collective agreement, to the employees' participation, or the right to information, we can state that without their effective regulation and enforcement, the protection and utilisation of any individual right can be more difficult to achieve. However, some years ago the problems of labour law and employment policy also seemed remote, with which the labour market of EU fights today, but it is necessary to find old-new solutions, and the collective rights inspired by the EPSR can be suitable for this role. At the same time, in order that the EPSR - and through it the collective rights of workers - could reach this goal it is necessary to resolve an inconsistency which now seems to be hypothetical. This relates, namely, to Article 16 of the CFREU which was quoted several times, and the social, labour law, and to a lesser extent, economic achievements to be reached within the framework of the EPSR.

Furthermore, the balance that is aimed by collective rights should be fulfilled not only between the interests of the social partners, but in general, also regarding the market, and the actors of the market. This may lead, in reference to economic nature rights, to new contradictions, and again, to the many times criticised collision between the economic and social interests. In order to avoid this problem it is necessary to strengthen the structure of collective labour law on the present basis. It is not probable if the economic freedoms supporting the competition would be left without attention because of the vigorous social policy due to the EPSR, since that would be counterproductive. However, a competition cannot function without workers and their communities, consequently, to reach the necessary balance quoted by the CJEU several times is as important as the traditional legal principles and rights of social content, and, additionally, the economic trends influencing the environment of labour market. This way, the duality of balance and social protection is indisputable and it is resolvable with difficulties, but in my opinion, the marginalisation of the questions of legal protection, and maybe its future support by the EPSR can be put on the agenda soon on the level of EU law, too. Surely, in this process the right to take collective action and bargaining, due to its extensive legal character and - the expected - efficiency, has to receive a central role.

77 Biasi, Marco: 'We will all laugh at gilded butterflies.' The shadow of antitrust law on the collective negotiation of fair fees for self-employed workers. European Labour Law Journal, 2018/4, 355-356. (doi: 10.1177/2031952518810640). 